\title{
The Morphotectonic Units of Ikaria Island - Contribution in the Natural Hazards Research
}

\author{
H. EFRAIMIADOU(1), ST. LOZIOS(1), N. EVELPIDOU(1)
}

\section{ABSTRACT}

Present morphological and tectonic image of Ikaria island is the complex result of both the temporal evolution of the island, as part of the geodynamical evolution of the Hellenic Arc, especially that of the last stages (from the upper Miocene and after), and the exogenous factors. Also human impact functions as an additional parameter for the formation of Ikaria geoenvironment.

According to field data and their analysis, computing and estimation which took part with the use of modern technologies (use of GIS, analysis of geographical and descriptive databases) the morphotectonic units of Ikaria Island were defined. The definition of the morphotectonic units was based on their special features and more precisely on the lithological differentiation (granite, metamorphic rocks and post alpine formations) as well as the complex ductile and brittle structures (large scale ductile shear-zones and brittle detachment faults, normal faults, strike-slip transfer faults and join sets) and the morphological features (slope distribution, asymmetry of the drainage system, planation surfaces, morphological discontinuities etc).

The synthesis of the special features of each morphotectonic unit in combination with the human impact (fires, overgrazing etc), defines the kind, the intensity and the geographical localization of the natural hazards which occur in various sites of the island, such as landslides, erosion, floods, seismic activity, relief changes, coastline changes etc.

Keywords: morphotectonic units, natural hazards research.

\section{ПЕРІАНЧН}

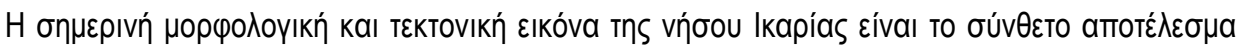

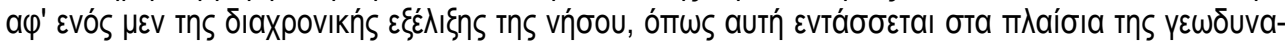

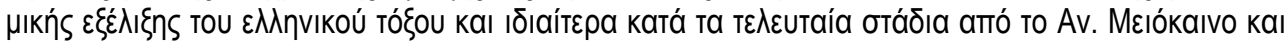

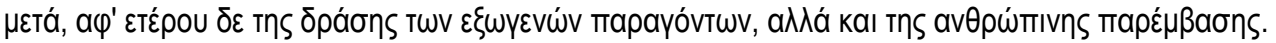

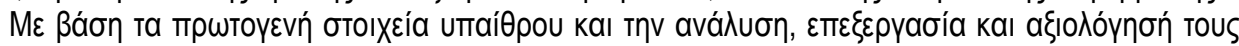

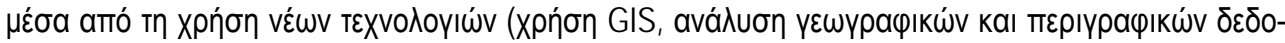

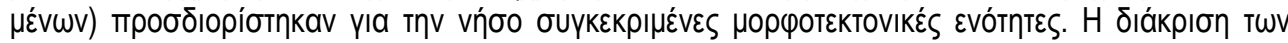

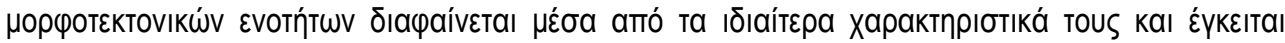

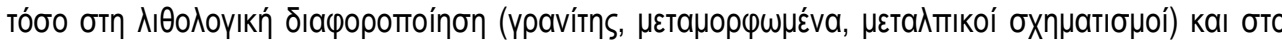

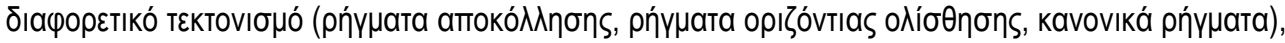

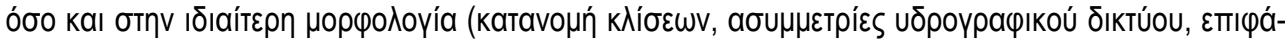

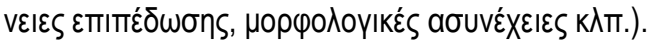

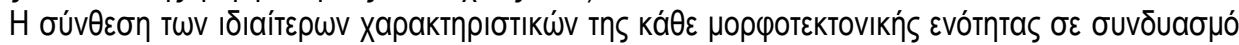

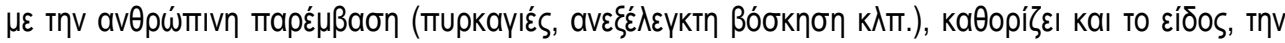

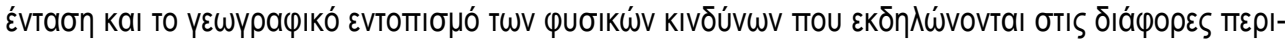

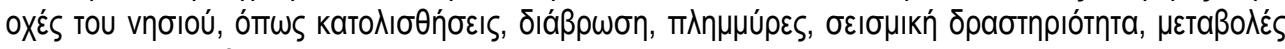

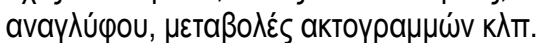

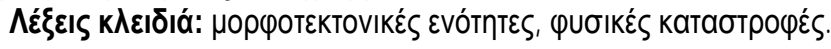

THE MORPHOTECTONIC UNITS OF IKARIA ISLAND - CONTRIBUTION IN THE NATURAL HAZARDS RESEARCH

1 National \& Kapodistrian University of Athens, Faculty of Geology and Geoenvironment, efraimiadou@gmail.com, slozios@geol.uoa.gr, evelpidou@geol.uoa.gr 


\section{REGIONAL SETTING}

Ikaria island belongs in the island complex of the Eastern Aegean with geographical coordinates N37040'40" kal E26021'55". It has a longitudinal form with axis direction in WNW -

ESE where the main mountainous mass is Atheras.

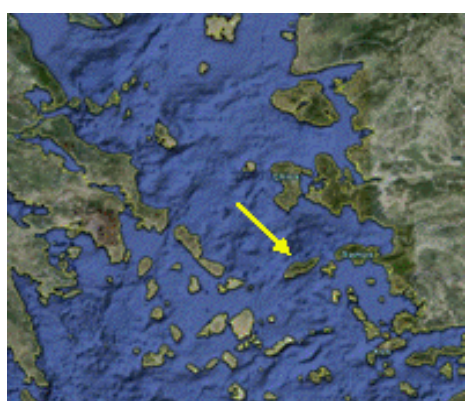

Figure 1: Geographical location of Ikaria island.

The topography is intense and mountainous. The high between the northern part of Ikaria, which is characterized by more or less gently dipping morphological slopes, and the southern part which is characterized by the small stream length of the drainage network, the steep morphological slopes, the intense linear erosion in addition with the lack of planation surfaces and the relatively linear coastline, reveals that the present morphology of Ikaria Island is the complex result of both the temporal morphotectonic evolution of the island, and the dynamic exogenous factors where human impact is concluded.

The geotectonic position of Ikaria island constitutes a transition zone between the "Cyclades Unit" and the "Pelagonian Unit" at the west and the "Menderes (Meander) mass" at the east (Ktenas \& Marinos 1969; Bozkurt \& Oberhansl 2001). According to Papanikolaou 1978, three geotectonic units can be distinguished: a) the upper Kefalas unit which represents relics of crystalline limestones and molassic sediments which belong to the Internal Hellenides, b) the middle Messaria unit which consists of alternations of marbles and phyllites homologous with the Cycladic blueschists unit and c) the lower Ikaria unit covers the larger area of the island and comprises mainly of gneiss and marbles. The Ikaria unit is also intruded by two syn- kinematic granitic bodies, the large l-type granite of Rahes which dominates at the western part of the island and the small S-type granite of Xylosirtis, at the south (Altherr et al. 1982, Papanikolaou et al. 1991). Finally Pliocene conglomerates have been developed along the NE part of the SE coastal zone of the island. The main tectonic structures are the older ductile shear zones and the youngest low angle normal faults (detachments) as well as the last tectonic events defined by high - angle normal faults and strike - slip faults (Fig.2).

\section{TECHNIQUES AND METHODOLOGY}

Extensive field work took place in order to collect data related to geology, tectonics and geomorphology of Ikaria island that compose the morphotectonic characteristics of the research area. Furthermore, an emphasis was given on various catastrophic phenomena (landslides, erosion, floods, coastal zone changes) that occur in many sites of the island after intense rainfalls. Fieldwork also took place for the confirmation of the results that were produced through the GIS analysis (Fig.3).

For the data processing, the development of thematic maps, the creation of data bases and the parallel management of them, the GIS MapInfo ver. 9 was used. This methodology was chosen because multi information layers were needed to be developed and analysed and GIS applications were used as the tool for the analysis and synthesis of the geographical and descriptive data.

\section{MORPHOTECTONIC DATA}

\section{Introduction}

According to the field data and the data produced by the GIS analysis, three morphotectonic units are distinguished from west to east; Units 1,2 , 3. Each of the three main morphotectonic units is distinguished in two subunits. Atheras is the main watershed of the island and it is the natural border that separates the subunits $1 \mathrm{a}-$ $1 b, 2 a-2 b, 3 a-3 b$ from north to south. Each of the units and subunits has its own morphotectonic characteristics related to the occurrence of natural hazards. The drainage network asym- 
metry is characteristic. As a result, the island is separated into the north and the south part where there is a contrast in the drainage basins slope and dimensions. Furthermore, the Ikaria "kink" - type shape distinguish a western part where the watershed and the coastline have a
NE-SW orientation, a central part with $\mathrm{E}-\mathrm{W}$ orientation and an eastern one with NE - SW orientation.

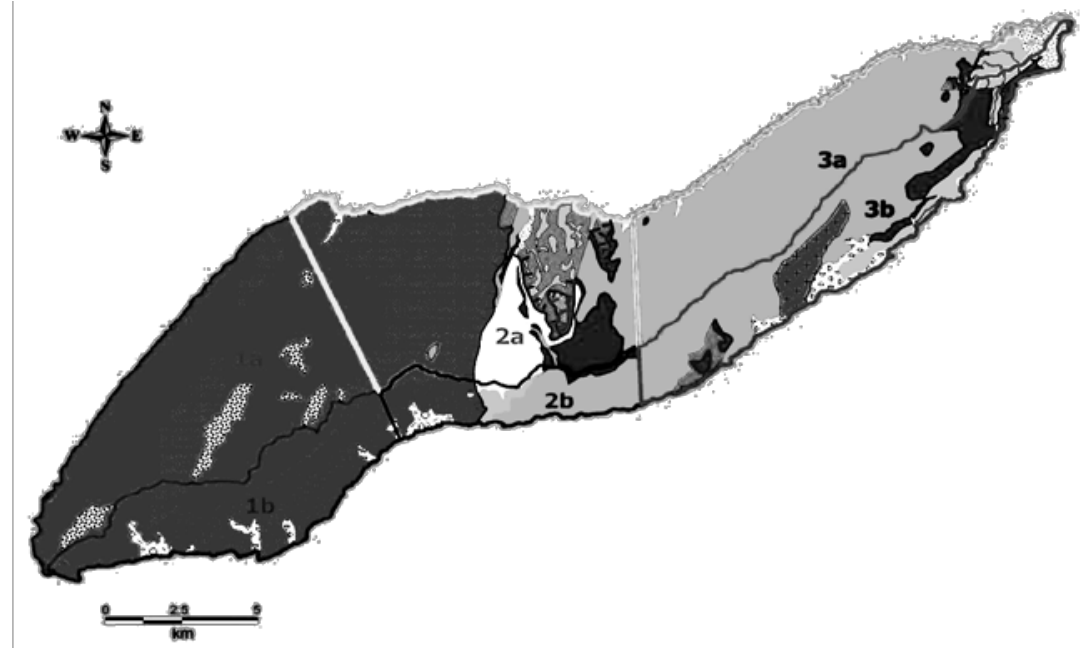

\section{Geological Formations}

$\square$ Coastal deposits: loose sand and unconsolidated cobbles

Alluvial deposits

Il Scree

Granites waste mantle

Chaotic granitic rockfalls and talus cones

Compact breccioconglomerates

Marine deposits

Xylosirtis Granite

Western Ikaria gneiss granite

Mylonitizated granite of Rahes
2 Granite of Rahes with pholidosis

Molassic ophiolitic formation

Crystallic limestone, Kefalas unit

Schist of Messaria unit

$\square$ Messaria marbles

$\square$ Marbles, amphibolites, schists alternations of Petropouli Unit

Pounta dolomite

Upper Pounta marbles

Gneiss of Plagia

Dolomitic marble of Nikari

Calcitic marble of Nikari

Figure 2. Geological Map of Ikaria island

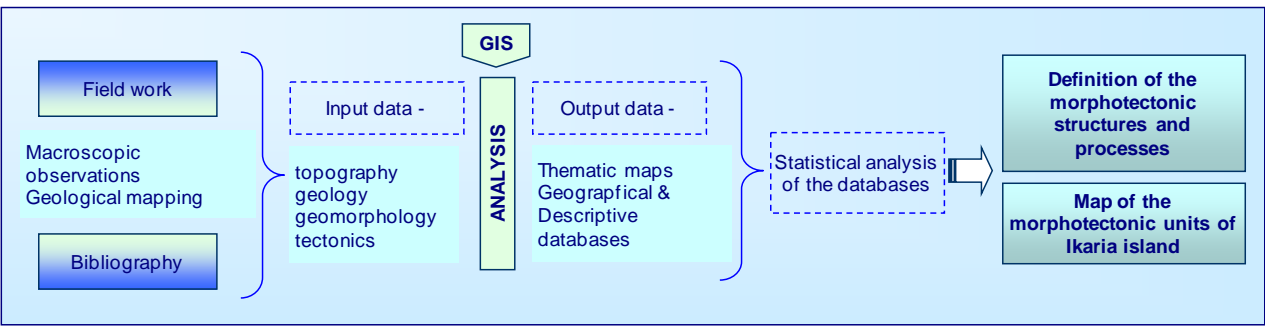

Figure 3. Flow diagram of the followed methodology 


\section{Morphological Slopes and discontinuities}

The slope map of Ikaria island was developed with the use of GIS. It is obvious that the southern part is characterized by an intense relief of higher inclinations ( $70 \%-80 \%)$ in relation to the northern part where the relief is smoother (Fig.4). In specific, the northeastern and southern parts are of very high inclinations while the middle part seems to be a transition zone to the lower inclinations $(0 \%-28 \%)$ that dominate at the northwestern part of the island. From the slope map, an extent planation surface was detected whose existence was verified also after the field work. This planation surface is located at the upland Pezi - Erifi (marked with the yellow arrow in figure 4) (Fig.5), in $800 \mathrm{~m}$ altitude, its surface is approximately $\sim 25 \mathrm{~km}^{2}$ and it has a low inclination $(<14 \%)$ to $\mathrm{N}$.

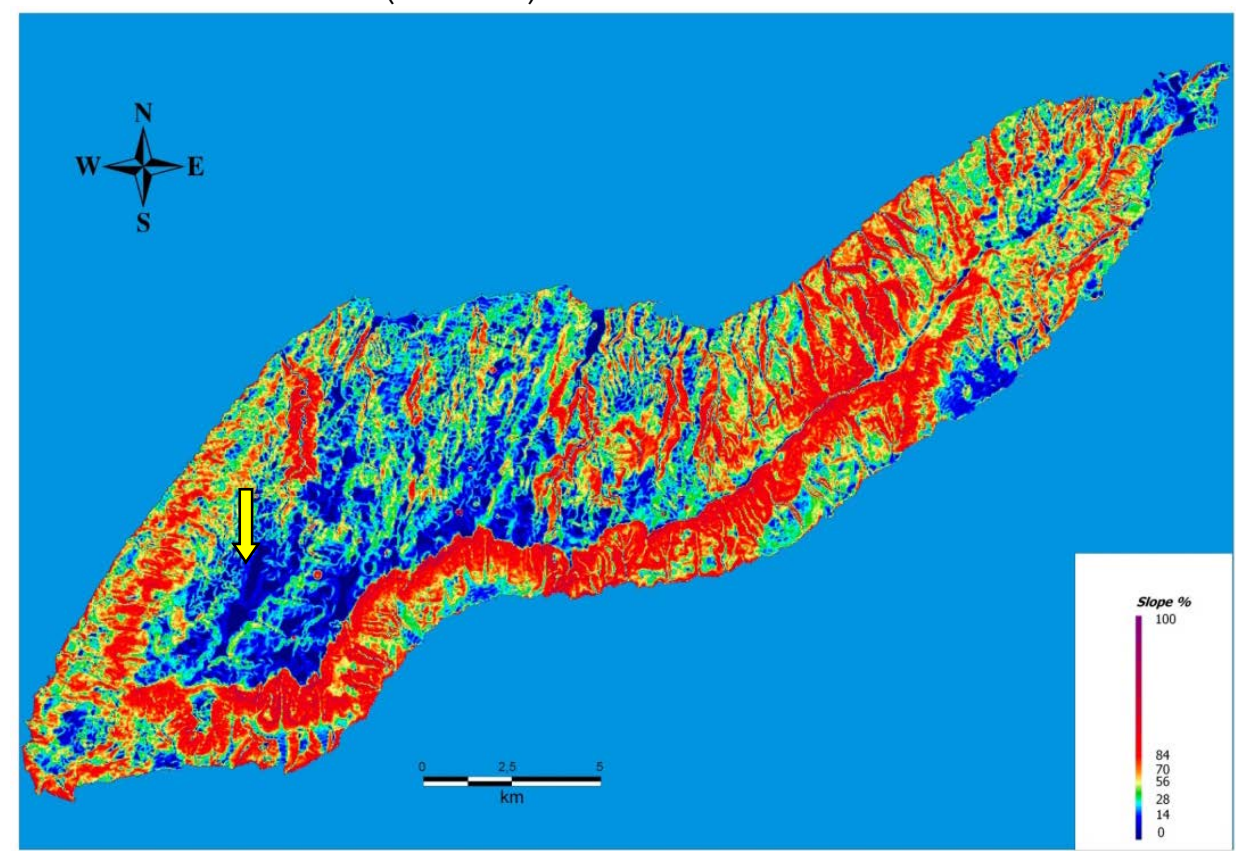

Figure 4. Slope map of Ikaria island

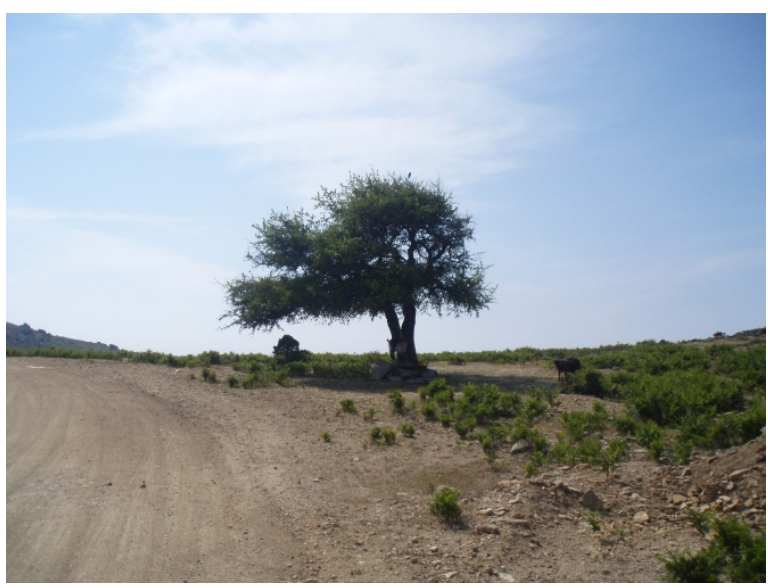

Figure 5. Pezi-Erifi planation surface 
Morphological discontinuities are associated with the areas mentioned above which are of very high slopes (>75\%). Through GIS analysis, the orientation of these morphological discontinuities were calculated (Fig. 6).

It is resulted that the morphological discontinuities orientation is changing from north to south and from west to east but it seems to be grouped according to some prevalent values. The northwestern part is characterized mainly by orientations of approximately $100^{\circ}$, the north and centered part of $20^{\circ}$ and the north-eastern part of $160^{\circ}$. The south-western part is characterized by orientations of $40^{\circ}-80^{\circ}$, the southern part of $100^{\circ}$ and the south-eastern part of $\sim 60^{\circ}$.

\section{Faults}

The present asymmetric relief of Ikaria Island corresponds to the asymmetric footwall updoming and the exhumation of the ductile extensional shear-zone during Upper Pliocene, which separates the granite and the Ikaria unit from the upper blue-schist Messaria unit. During the progressive updoming, the ductile shear zone moved to the brittle, upper parts of the crust and today is juxtaposed with the lower of the two main extensional detachment faults (Fig. 2) of the island (Kumerics et al. 2005). The other one, is not connected with an underlying ductile shear zone and separates the blueschist unit from the Pliocene conglomerates. There are some places along the SE coastal zone of the island, where we can recognize the low-angle fault surface (Fig. 7), but there are, also, some others where the detachment accompanied by a cataclastic zone. The most of the smaller scale faults of the island are localized at the central part, and rarely at the area between St. Kirikos and Fanari, cutting the upper blue schist unit (see Fig. 2). The main fault direction is around E-W, but NE-SW and NW-SE (and rarely other) directions also occur. All these faults seem to be related with the lower detachment fault, representing the "upper plate" brittle extensional deformation, showing (according to Kumerics et al 2005) a top-to-the-NNE displacement of the hanging wall.

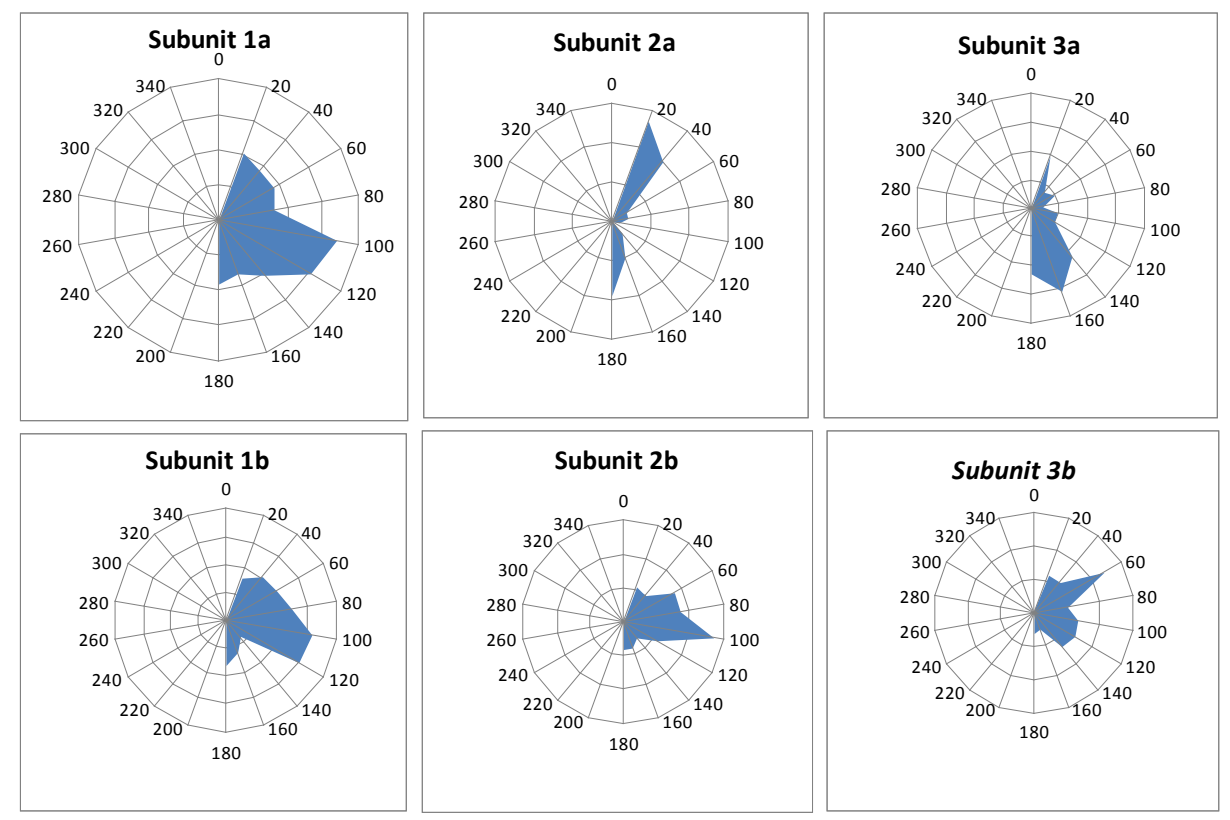

Figure 6. Morphological discontinuities orientation 


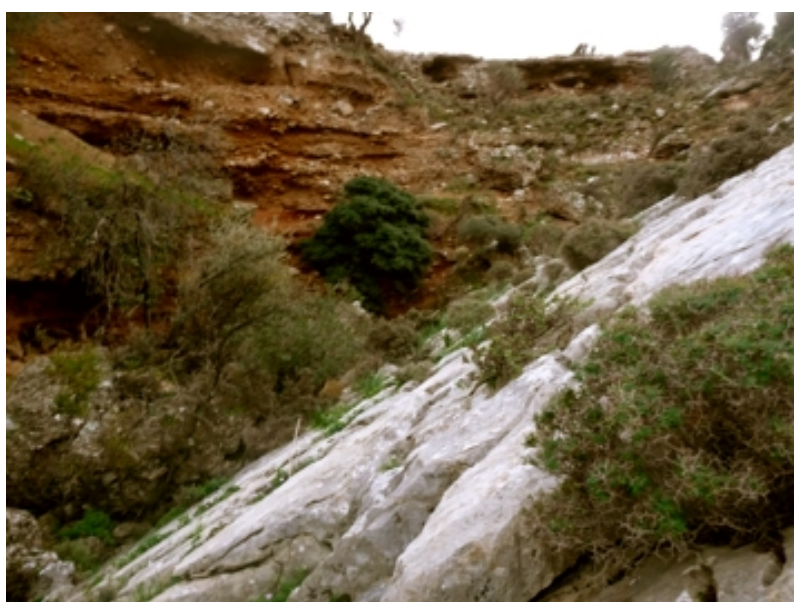

Figure 7. The upper detachment fault surface (30/105), which separates the Pliocene conglomerates from the marbles of the blue schist unit. As it seems the marble is jointed and strongly brecciated (cataclasite zone). Near coastal road, about $7 \mathrm{~km}$ from St. Kirikos to Fanari.

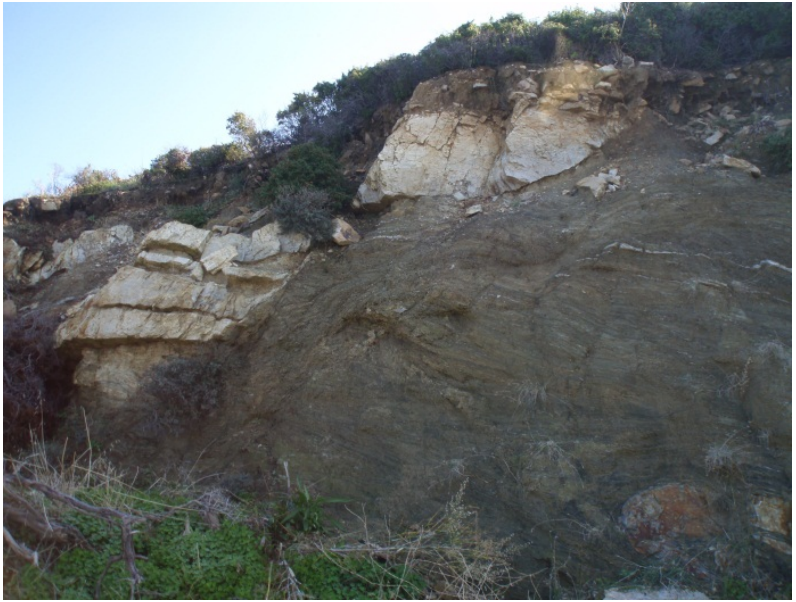

Figure 8. NNE dipping normal fault near Evdilos, cutting the blueschist unit.

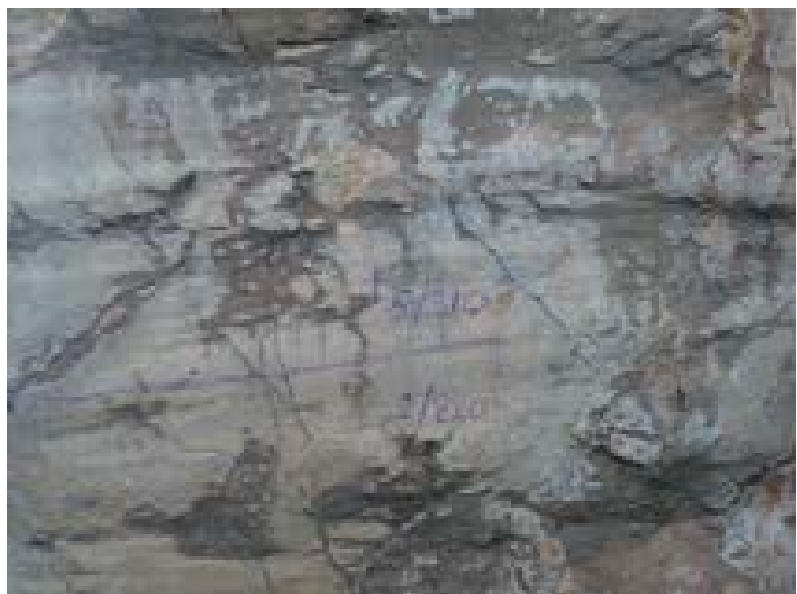

Figure 9. NE-SW dextral strike-slip fault at the SE coastal zone of the Island. 
NE- or NW-striking strike-slip faults also occur in the island, like the one presenting in Fig. 9. These faults either represent transfer faults linking different segments of normal faults, connected with the Upper Miocene - Upper Pleistocene extensional tectonics, or must be related with the Quaternary transpressional regime, described, for the major area, by Lykousis et al 1995, from submarine data.

\section{Drainage Network}

The hydrographical network is characterized by the development of streams of permanent and non permanent flow. The drainage networks are in a continual parallel order and as a result the basins are being limited from both sides. The main watershed of Ikaria island is Atheras which is located only $2.5 \mathrm{~km}$ from the southern coastal zone and as a result the streams of the southern part of the island have a limited length as well as the drainage basins which are of limited area. Furthermore, at the southern part drainage basins are characterized of high inclinations ( $>28,9 \%$ ) and this is a parameter why the downcutting erosion is intense while the streams
According to field work, it seems that the morphological discontinuities are associated with the tectonic structures. This relation is obvious through the congruency of the structures orientation. The northwestern part is characterized mainly by orientations of approximately $100^{\circ}$, the north - eastern part of $20^{\circ}$. The southwestern part is characterized by orientations of $\sim 40^{\circ}$ and the south-eastern part of $\sim 100^{\circ}$ (Fig. 6) tend to reach the sea level in a much shorter distance enforcing the regression erosion (Fig. 10).

On the contrary, the northern part of the island is characterized by developed branches of more extensive length and of larger drainage basins. Drainage basins slopes are generally smoother $(<24 \%)$. Halaris river is the main hydrographical network of western part of the island. Its class is IV and its drainage basin covers an area of $20.64 \mathrm{~km}^{2}$. Voutsidies river is also a developed hydrographical network of the northern part. Its class is IV and its drainage basin covers an area of $21.4 \mathrm{~km}^{2}$.

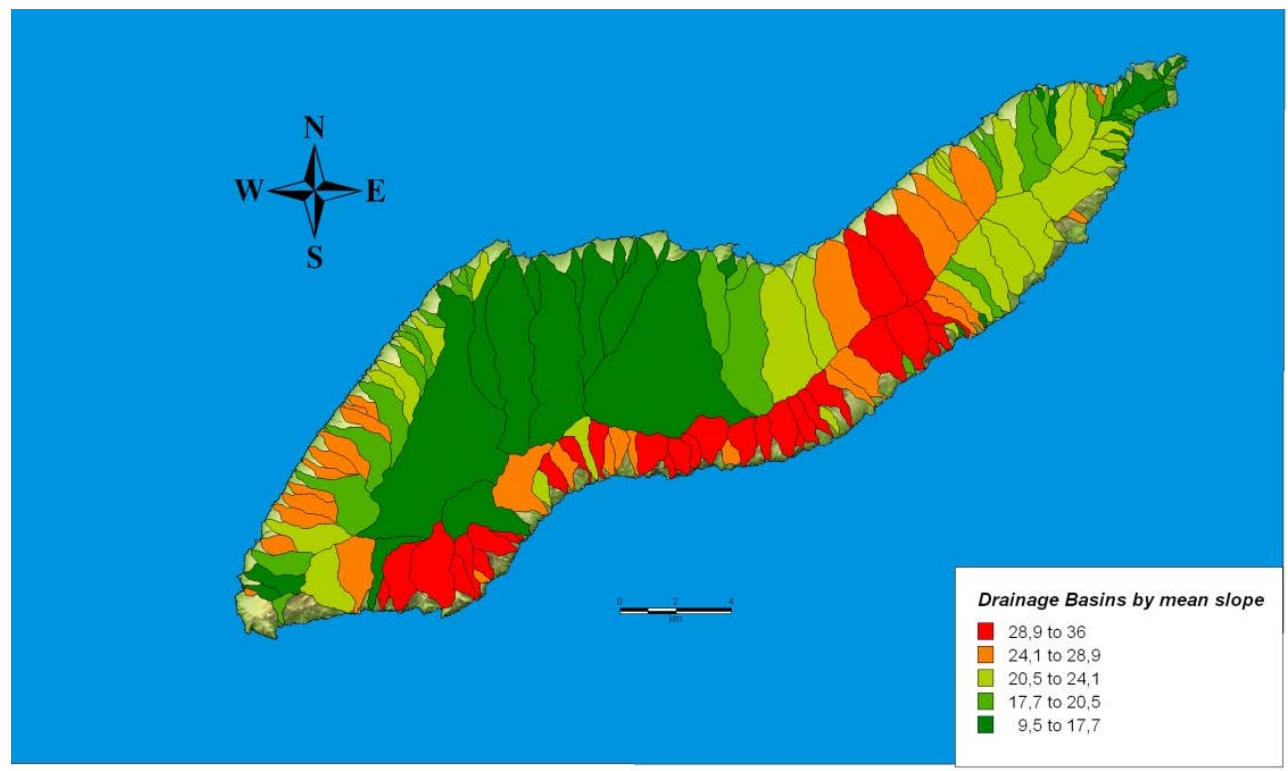

Figure 10. Map of drainage basins by mean slope 
The drainage network orientation was calculated through GIS. It is resulted that its orientation is changing from north to south and from west to east but it seems to be grouped according to some prevalent values. The northern part is characterized mainly by orientations of approximately $20^{\circ}$ while at the north-western part change to $100^{\circ}-120^{\circ}$. At the south-western part the orientation is 1200 - 1400 while at the middle southern part ranges from $1600-1800$. The south-eastern part is characterized by the same orientation as the north-western part $(\sim 1200)$ (Fig. 11).

\section{RESULTS \& DISCUSSION}

In general, there is a dynamic relation between tectonics and geomorphology. Tectonic structures control and define the geometry and orientation of the morphological characteristics. Faults and morphological discontinuities orientation are related with a specific orientation as well as the sudden flow changes of the drainage network. The slope differention, the geometry and orientation of the morphotectonic characteristics, their spatial analysis as well as the differential processes that take place on the different geological formations lead the research at the definition of the morphotectonic units of Ikaria island.

Three morphotectonic units are distinguished from west to east, Units 1,2 and 3, according to the impacts of the endogenous and exogenous processes that affect the morphology of Ikaria. Each of the 3 main morphotectonic units is distinguished in two subunits. Atheras is the main watershed of the island and it is the natural border that separates the subunits $1 \mathrm{a}-$ $1 b, 2 a-2 b, 3 a-3 b$ from north to south (Fig.12).

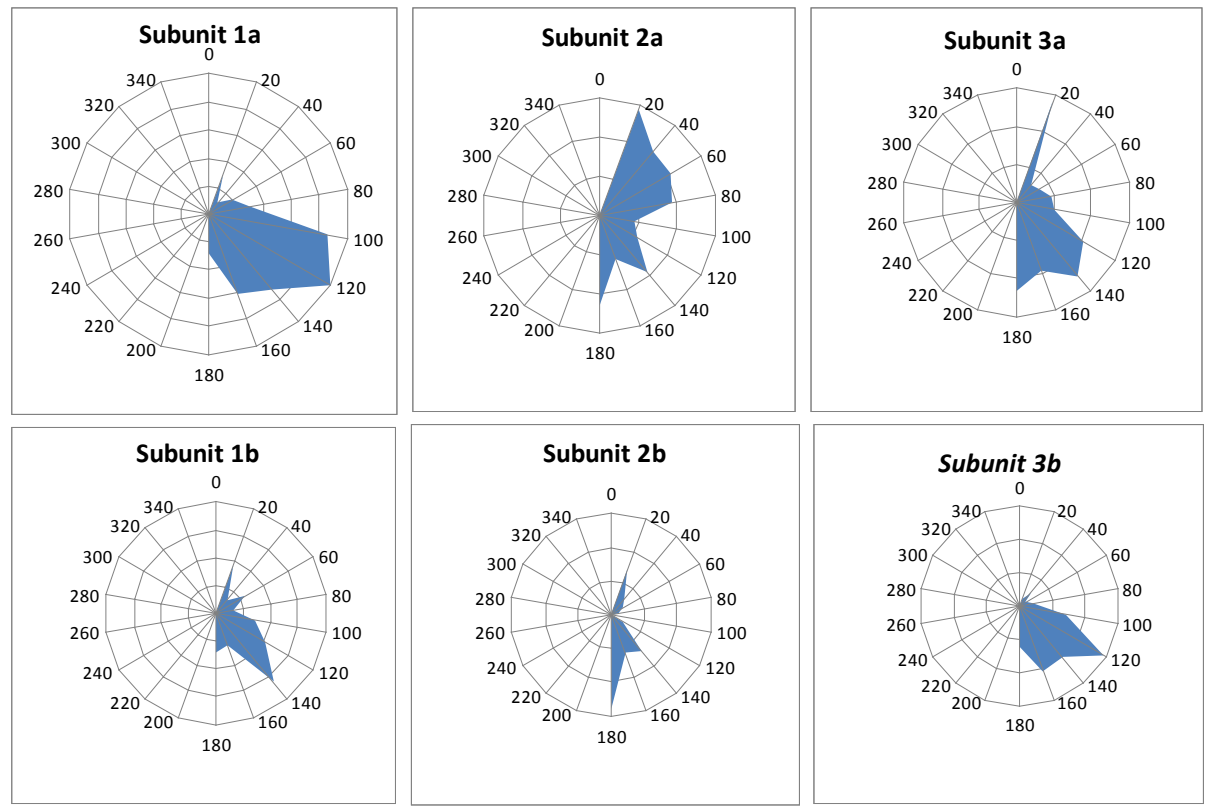

Figure 11. Drainage network orientation 


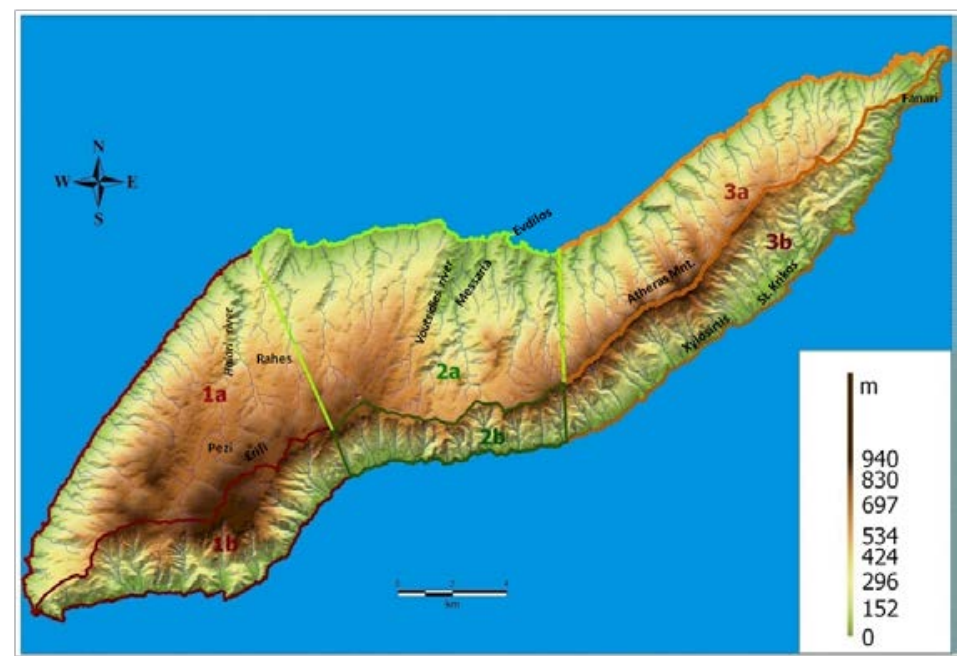

Figure 12. Map of the morphotectonic units of Ikaria island
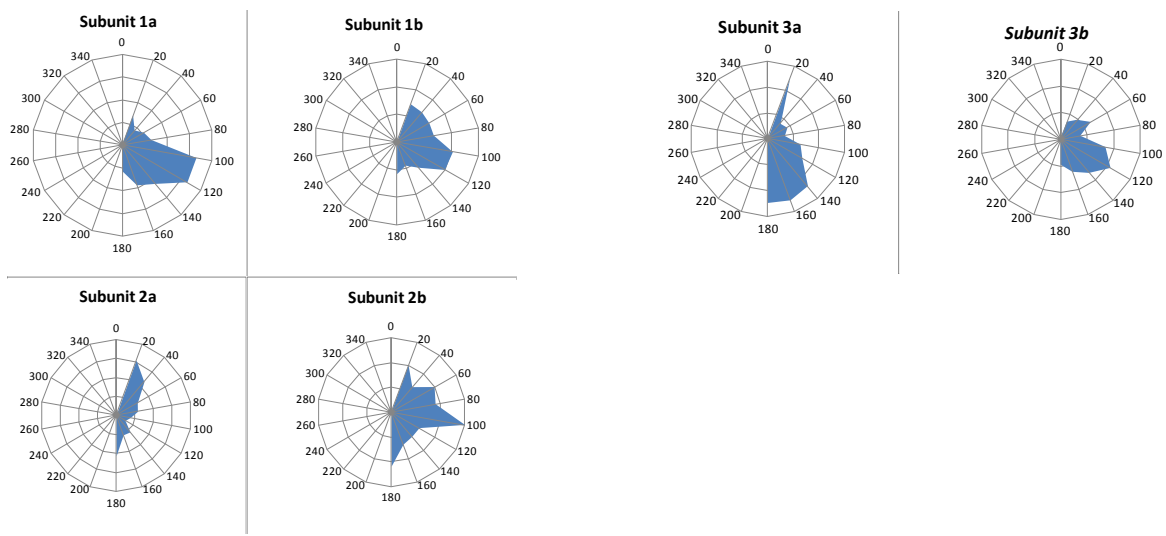

Figure 13. Main morphotectonic characteristics orientation (faults, rivers, morphological discontinuities)

Table 1. Table of the main characteristics of the morphotectonic units of Ikaria island

\begin{tabular}{|c|c|c|c|c|}
\hline & & Unit_1 & Unit_2 & Unit_3 \\
\hline \multirow{6}{*}{ Subunit a } & main lithology & | Rahes granite & $\begin{array}{l}\text { Rahes granite, schists and } \\
\text { marbles alternations }\end{array}$ & | Plagia gneiss \\
\hline & \begin{tabular}{|l}
$\begin{array}{l}\text { area of the IV class drainage } \\
\text { basins }\end{array}$ \\
\end{tabular} & $20.63 \mathrm{~km}^{2}$ & $21.4 \mathrm{~km}^{2}$ & \\
\hline & planation surfaces & $\begin{array}{l}800 \mathrm{~m}, \\
25 \mathrm{~km}^{2}, \text { slope } \\
\text { to N }\end{array}$ & ort N70E and incl. $0-100^{\circ} \mathrm{N}$ & \\
\hline & \begin{tabular}{|l} 
mean slope \% \\
\end{tabular} & 17.70 & 17.19 & 24.27 \\
\hline & $\begin{array}{l}\begin{array}{l}\text { morphological discontinuities } \\
\text { orientation, degrees }\end{array} \\
\end{array}$ & $80-100$ & $0-20$ & , tover \\
\hline & $\begin{array}{l}\text { hydrographical network } \\
\text { orientation, degrees }\end{array}$ & $100-120$ & $0-20$ & \\
\hline \multirow{4}{*}{ Subunit b } & \begin{tabular}{|l} 
main lithology \\
mean slope \%
\end{tabular} & \begin{tabular}{|c|} 
Rahes granite \\
26.08
\end{tabular} & $\begin{array}{l}\text { schists and marbles alternations } \\
3958 \text { at }\end{array}$ & \begin{tabular}{|l} 
Plagia gneiss \\
2374
\end{tabular} \\
\hline & $\begin{array}{l}\text { mean slope } \% \\
\text { tault orientation, degrees }\end{array}$ & $\frac{20.08}{20-40}$ & $\begin{array}{r}2.58 \\
80-100\end{array}$ & $\frac{23.14}{80-100}$ \\
\hline & $\begin{array}{l}\text { morphological discontinuities } \\
\text { orientation, degrees }\end{array}$ & $40-80$ & $80-100$ & $40-60$ \\
\hline & $\begin{array}{l}\text { hydrographical network } \\
\text { orientation, degrees }\end{array}$ & $120-140$ & $160-180$ & $100-120$ \\
\hline
\end{tabular}



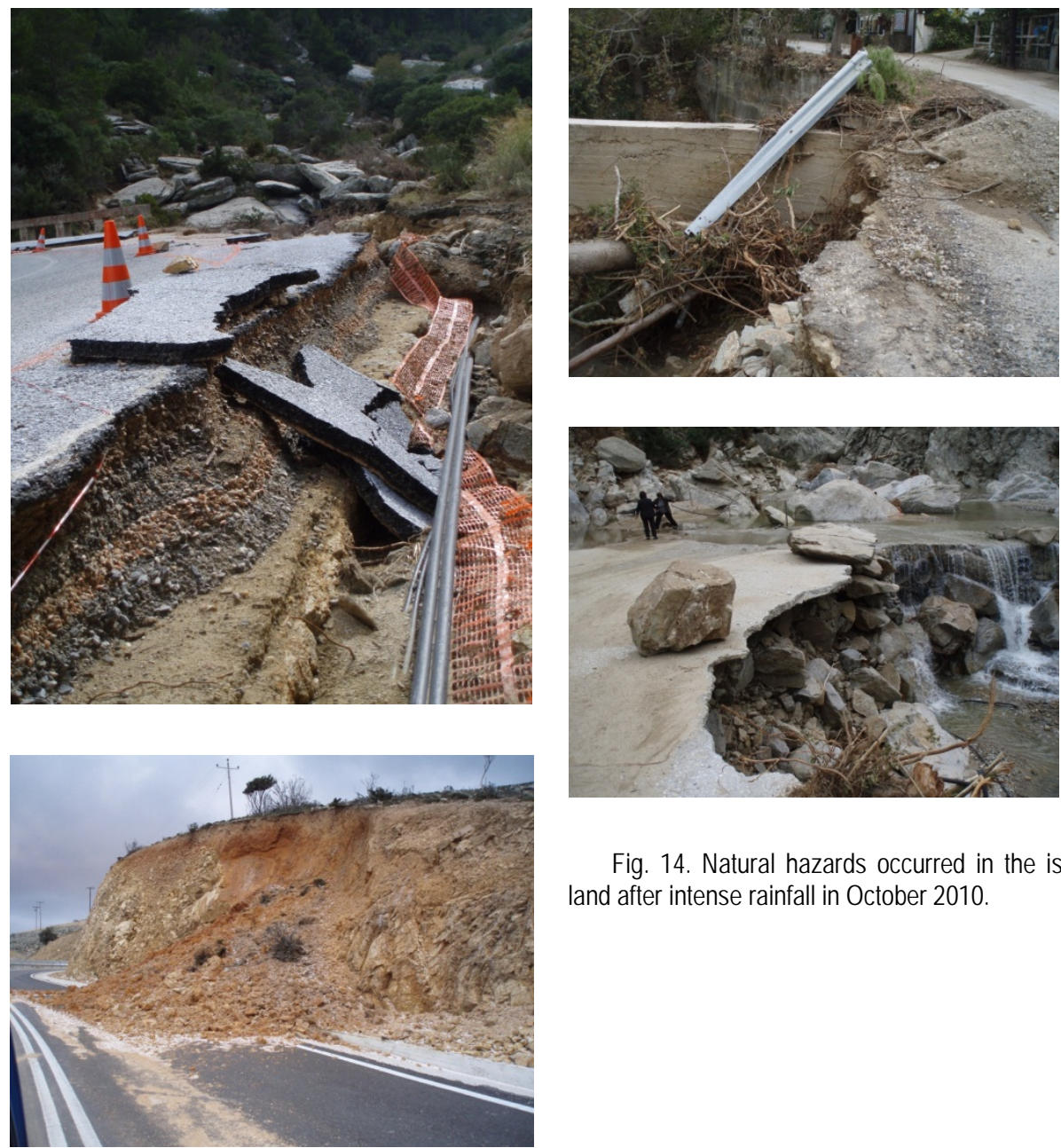

Fig. 14. Natural hazards occurred in the island after intense rainfall in October 2010.

The orientation of the main morphotectonic characteristics (faults, rivers, morphological discontinuities) are summarized in Fig. 13 and Table 1.

Many natural hazards such as land slides, rockfalls, soil erosion, floods, relief changes and coastline changes occur in many sites of Ikaria island after intense rainfalls (Fig. 14). The catastrophic phenomena have as a result the downgrading of the human and natural environment. The impacts are more intent at the southern part, where the drainage basins slopes are higher as well as the erosion rate. Drainage basins such as that of Halaris which is of an extent surface, while the downstream area is characterized by high slopes, the surface flow is enhanced and as a result the erosion rate is accelerated. Morphotectonic characteristics in combination with the human interventions control the occurrence, the location and the intensity of the natural hazards. The Natural hazards research may be systematized through the definition of the morphotectonic units. Modelling in addition with the human impact results, the 
managing of the natural hazards which affects seriously the environment and the socioeconomic status of the island is possible.

\section{BIBLIOGRAPHY}

Altherr, R., H. Kreuzer, I, Wendt, H. Lenz, G.A. Wagner, J. Keller, W. Harre \& A. Hohndorf, 1982. A Late Oligocene/ Early Miocene High Temperature Belt in the Attic-Cycladic Crystalline Complex (SE Pelagonian, Greece), Geol. Jb. E 23: 97-164

Bozkurt E. and Oberhansli R., 2001. Menderes Massif (Western Turkey): structural, metamorphic and magmatic evolution - a synthesis. International Journal of Earth Sciences 89, 679 - 708.

Ktenas K., Marinos P. G., 1969. Ikaria island geology, IGME, vol. XIII VOL Geological and Geophysical research, No 2, Athens.

Kumerics Chr., Ring U., Brichau St., Glodny J., Monie P., 2005. The extensional Messaria shear zone and associated brittle detachment faults, Aegean Sea, Greece, Journal of the Geological Society, London, Vol. 162, pp.701 - 721. Printed in Great Britain.

Lykousis V., Anagnostou C., Pavlakis P., Rousakis G., Alexandri M., 1995. Quartenary sedimentary history and neotectonic evolution of the eastern part of Central Aegean Sea, Greece, Marine Geology 128, pp $59-71$.

Papanikolaou D., 1978. Contribution in the geology of Ikaria island (Aegean Sea), Annales geologiques des pays helleniques, 1e Series T.XXIX.

Papanikolaou D., Sakellariou D., Leventis A., 1991. Microtectonic observations at Ikaria granites, Bulletin of the Geological Society of Greece, vol.XXVI 421-437. 